\title{
固化改良土と突固め土からなる複合土の分割載荷型一面せん断試験による強度特性 一砕・転圧盛土工法によるフィルダムの堤体改修における固化改良土の強度許容値の検討一
}

\author{
福島 伸二 ${ }^{1}$, 北島 明 ${ }^{2}$ \\ 1 株式会社フジタ・建設本部 \\ 2 株式会社フジタ・技術センター
}

概 要

砕・転圧盛土工法は老朽化したフィルダムやため池の堤体改修（耐震補強, 漏水防止）を, 貯水池内の底 泥土をセメント系固化材により固化改良した築堤土, いわゆる砕・転圧土により行うもので，これまでに 12 事例に適用されている。この工法は，所要の強度と遮水性を有する築堤土が人工的に準備できるため， 既設堤体に砕・転圧土ゾーンによる腹付け盛土あるいは押え盛土を急勾配法面で行えるものの, 堤体改修 ゾーニングにおける砕・転圧土ゾーンとこれに隣接する既設堤体の間に極端な強度差が生じないことが必 要である。本稿は砕・転圧盛土工法による堤体改修において, 砕・転圧土ゾーンと隣接の既設堤体の間に極 端な強度差が生じないように, 砕・転圧土により改修した堤体全体の破壊モードを再現した分割載荷型一 面せん断試験により砕・転圧土ゾーンの強度における許容值について検討した結果を報告する。

キーワード：フィルダム，堤体改修，底泥土，固化改良，複合土

\section{1. はじめに}

砕・転圧盛土工法 ${ }^{12)}$ (は, 築造年代の古い老朽化したフィ ルダムやため池の耐震補強や漏水防止などのための堤体 改修技術であり，堤体改修に必要な築堤土の入手難と貯水 池内に堆積した底泥土の除去を同時に解決すべく開発さ れ, 池内の底泥土をセメント系固化材により固化改良して 築堤土（砕・転圧土）として利用するもので，これまでに 12 事例に適用されている ${ }^{3)}$ 。

砕・転圧盛土工法は所要の強度と遮水性を有する築堤土 を人工的に準備できるため, 堤体改修のための既設堤体へ の腹付け, あるいは押え盛土を急勾配法面により行うこと が可能であり, 改修に必要な築堤土量が少ないことや貯水 量の減少がない利点を有している。しかし, 砕・転圧土ゾ ーンの強度が隣接する既設堤体に期待される強度より高 $<$, 堤体全体が砕・転圧土ゾーンと既設堤体の間で強度特 性の異なるゾーン型構造となるため, これらが一体として 外力に抵抗するには両者間の強度特性の相違が悪影響を 与えないことが必要である。したがって, 堤体改修ゾーニ ングは砕・転圧土ゾーンとこれに隣接寸る既設堤体との間 で極端な強度差が生じないように, 砕・転圧土ゾーンの強 度に隣接する既設堤体に期待できる強度に応じた許容值 を設定し，これを超えないように決定しなければならない。
本稿では，砕·転圧盛土工法による堤体改修ゾーニング において砕・転圧土ゾーンとこれに隣接する既設堤体との 間に極端な強度差が生じないようにするために，砕・転圧 土により改修した堤体全体の破壊モードを再現した分割 載荷型一面せん断試験により, 砕・転圧土ゾーンの強度に おける許容值について検討した結果を報告する。

\section{2. 砕・転圧盛土エ法による堤体改修}

\section{1 砕・転圧盛土工法の概要}

砕·転圧盛土工法 ${ }^{1)}{ }^{2)}$ は，図-1 に概念的に示すように, 底泥土をセメント系固化材により固化改良して築堤土を 準備し，堤体の補強や漏水防止のための築堤を行うもの である。築堤は一定の初期固化期間 $t_{\mathrm{S}}$ だけ固化させた底 泥土（これを初期固化土という）を規定の最大粒径 $D_{\text {max }}$ に解砕して，通常土と同様に一定層厚に撒出し・敷均し てから転圧して一層毎に行う（これを砕·転圧土という）。 砕・転圧土の強度は初期固化土を解砕・転圧寸るまでの 初期固化日数 $t_{\mathrm{S}}$ とそれからの経過期閒 $t_{\mathrm{CC}}$ を合わせた $t=t_{\mathrm{S}}$ $+t_{\mathrm{CC}}$ に関係し, 特に $t_{\mathrm{S}}$ が解砕・転圧後の再固化強度の発現 に強く影響する。また， $D_{\max }$ は強度と遮水性の両方に影 響し， $D_{\max }$ を大きくした砕・転圧土ほど強度が大きく，透 水係数も大きくなる。このため, 砕・転圧土により所要の 


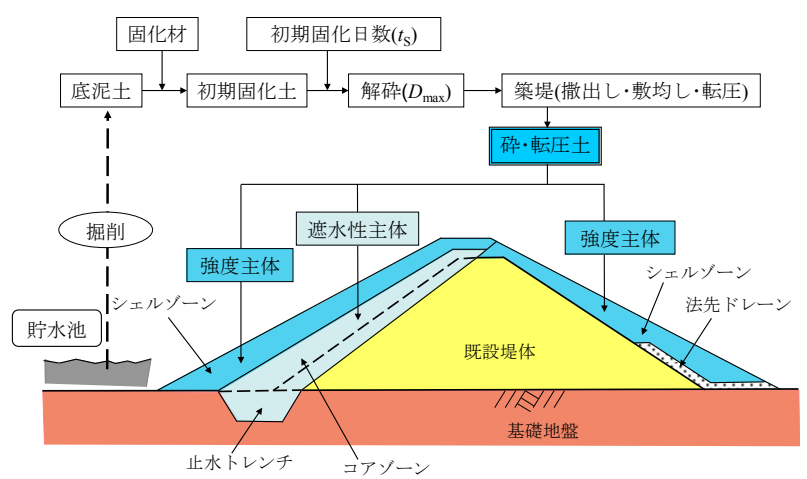

図 1 砕・転圧盛土工法の概要

強度と遮水性を有する堤体を築造するには $t_{\mathrm{S}}$ と $D_{\max }$ を適 切に管理する必要がある。従来, 単なる底泥土の固化土 （初期固化土に相当）は強度を固化材添加量の加減によ り容易に制御できるが，通常の築堤土に比較して破壊ひ ずみが小さく脆性的なひずみ軟化型の応力〜ひずみ特性 にあり，既設堤体との変形性の相違に起因したクラック が生じやすく貯水を目的とした堤体には使用できなかっ た。砕・転圧盛土工法はこのような固化土を築堤土に使用 する場合の問題点を, 初期固化させた底泥土を固化途上 中に解砕して通常の築堤土と同様に転圧して築堤すると, 再固化時の応力〜ひずみ特性が通常の築堤土に類似した ひずみ硬化型になる性質を利用して既設堤体との密着性 を良くしたものである。

\section{2 砕・転圧盛土工法により改修した堤体の特徵}

フィルダムやため池における従来の堤体改修は, 図 2 の 上図に概念的に示寸ように，既設堤体の上・下流側を一部 掘削除去し，上流側には補強用のシェルゾーンを腹付ける， 漏水防止が必要となる場合にはさらに遮水用のコアゾー ンを追加し，下流側には補強用のシェルゾーンを腹付ける か，押え盛土をすることが基本となろう。しかしながら， 通常の土質材料による築堤土が遮水性と強度の両面に優 れていないため, コアゾーンは遮水性に優れた築堤土によ り, シェルゾーンは強度に優れた築堤土によりそれぞれ築 造することになる。シェルゾーンには既設堤体からの掘削 土を流用することもあるが (この場合のシェルゾーンはラ ンダムゾーンと呼ばれることもある)，ダムサイト近傍に 強度に優れた築堤土を求める必要がある。コアゾーンに使 用する遮水性に優れた築堤土もダムサイトの近傍に求め ることが基本となろう。

これに対して, 砕·転圧盛土工法による堤体改修は, 築 堤土の強度を固化材添加量の加減により任意に設定でき, かつ細粒分を多く含む底泥土を原料土としているため遮 水性も有するように準備できるので，上流側にコアゾーン だけを腹付ければ補強と漏水防止を同時に達成すること ができる。既設堤体からの掘削土は砕・転圧土ゾーンの外 側に腹付ければ工事発生土を有効利用でき場外処分も発 生しない。堤体改修ゾーニングにおける特徴は, 図 2 の下

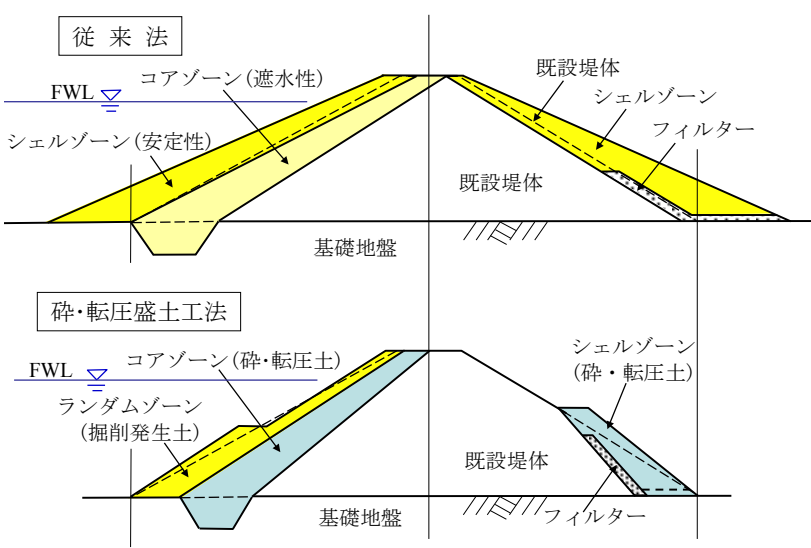

図 2 砕・転圧盛土工法による堤体改修ゾーニングの基本

図に概念的に示すように, 通常の築堤土による改修に比較 して急勾配断面が可能で, 改修後の堤体を既設堤体内にほ ぼ収められるので土工量を大幅に削減でき，かつ貯水量の 減少を無くすことができる効果がある。

研·転圧土ゾーンと既設堤体からなる新堤体は，すべり 面の全長に占める砕・転圧土ゾーンの割合が小さいことか ら，安定計算においては砕・転圧土ゾーンと既設堤体が一 体として挙動する複合土地盤として扱い，内部を通るす心゙ り面を均一型や中央コア型のフィルダムにおいて仮定さ れる円弧とすることを前提としている。

砕·転圧盛土工法による堤体改修ゾーニングのうち, 砕. 転圧土ゾーンは内部摩擦角による成分が小さく粘着力に 卓越した強度特性となり, 既設堤体は多少の粘着力を期待 できるもののほとんどが内部摩擦角からなる強度特性に ある。砕・転圧盛土工法が急勾配のゾーニングにより既設 堤体断面内で堤体改修できる利点を生かして，砕・転圧土 ゾーンの強度は隣接する既設堤体に期待できる強度に関 係するものの，隣接する既設堤体より高い值に設定される ため, 砕・転圧土ゾーンと既設堤体の間に大きな強度差が 生じることになる。したがって，砕・転圧土ゾーンを含む 堤体全体が複合土地盤として扱えるためには, 堤体ゾーニ ングは砕・転圧土ゾーンと既設堤体の間の強度差が極端に 大きくならないように決定する必要があり, 砕・転圧土ゾ ーンに付与する強度の大きさに既設堤体の強度に応じて 許容值を設定しなければならない。

\section{3. 砕・転圧土により改修した堤体のモデル化試験}

\section{1 分割載荷型一面せん断試験機}

砕・転圧盛土工法により図2の下図に示したように堤体 改修を行なった場合を想定すると，堤体全体は強度レベル が異なる既設堤体，砕・転圧土ゾーン，既設堤体からの掘 削土によるランダムゾーンなどからなるゾーン型構造と なる。砕・転圧土ゾーンと既設堤体の間における強度差の 許容值について, ゾーン型構造堤体の円弧すべり面による 破壊モードを図3に概念的に示すように分割型載荷型一面 


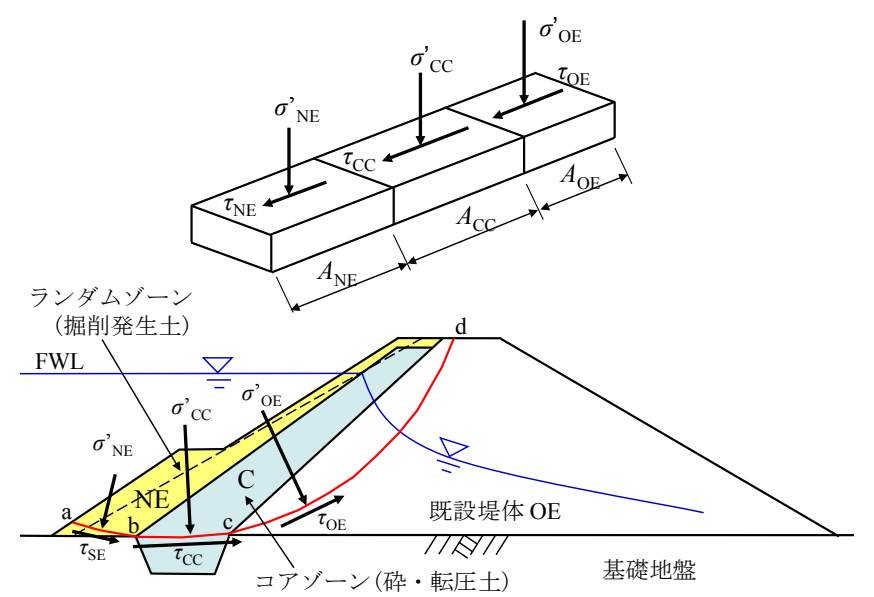

図3 砕·転圧盛土工法による堤体改修におけるゾーニング

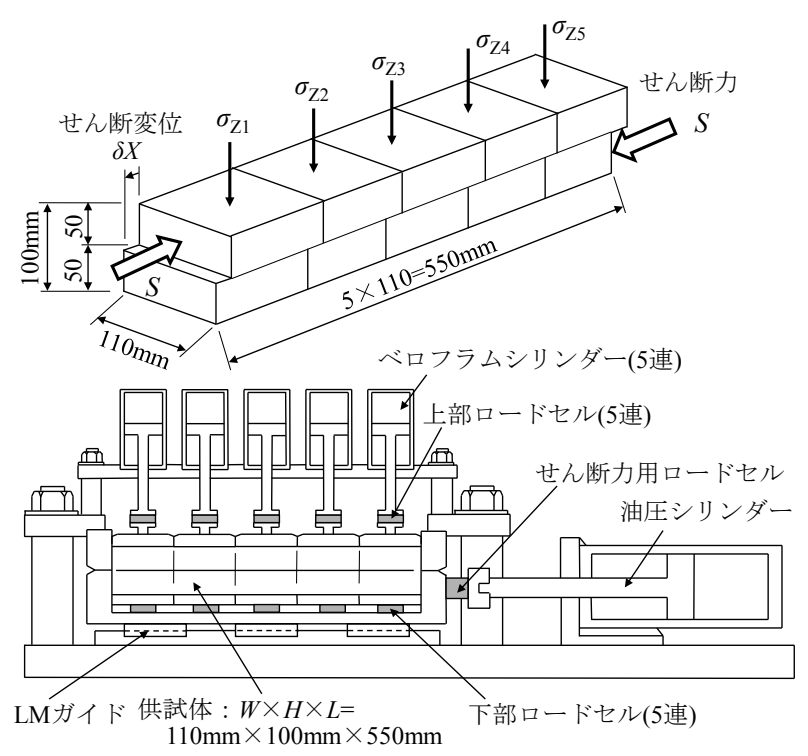

図 4 分割載荷型一面せん断試験概念図

せん断試験機によりモデル化し, 砕・転圧土部の強度のみ を3種類に変えて実施した試験により検討した。

分割型載荷型一面せん断試験機は図4に示すような細長 い直方体形状の供試体を5つに分割して，各分割部にそれ ぞれ独立に垂直応力 $\sigma_{Z}$ を載荷できるようにしたものであ る。供試体の各分割部の $\sigma_{\mathrm{Z}}$ を独立に載荷できるようにした 理由は, 強度変形特性が異なる供試体部分に一定の垂直応 力を加えることがきるようにするためである。分割載荷型 一面せん断試験機の全景を写真1に, せん断箱の一部を写 真 2 にれぞれ示す。

供試体は幅 $W=110 \mathrm{~mm}$, 高さ $H=100 \mathrm{~mm}$, 長さ $L=5 \times 110=$ $550 \mathrm{~mm}$ であり, 5 分割したうちの砕・転圧土部のせん断面 積 $A_{\mathrm{CC}}$ と, それ以外の堤体部を想定した突固め土部のせん 断面積 $A_{\mathrm{S}}$ の割合を種々変えて作製した。この砕・転圧土 と突固め土からなる供試体は強度特性の異なる土を合わ せたものなので，合成土と称することにする。合成土の供 試体は全せん断面積 $A\left(=A_{\mathrm{CC}}+A_{\mathrm{S}}=W \cdot L\right)$ に占める砕·転圧 土部のせん断面積 $A_{\mathrm{CC}}$ が占める面積構成比

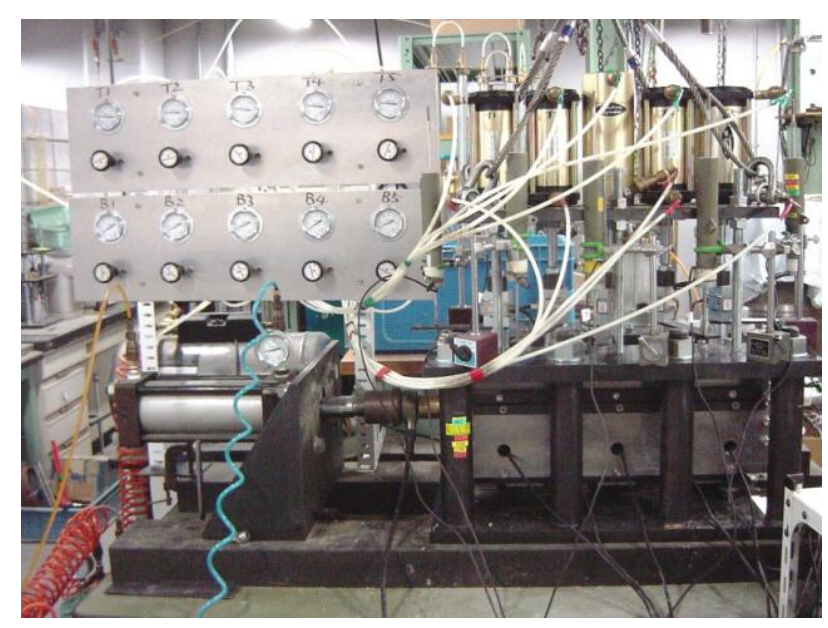

写真 1 分割載荷型一面せん断試験機

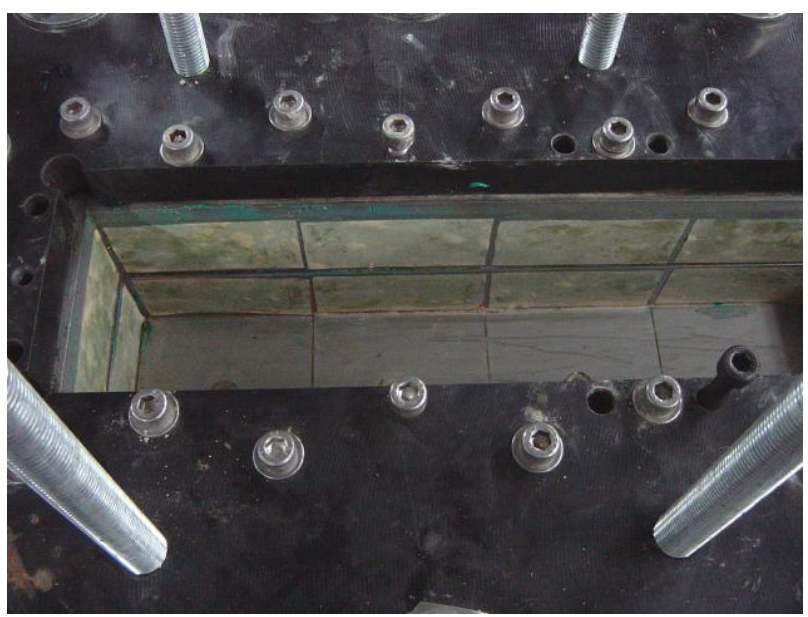

写真 2 分割載荷型一面せん断試験機のせん断箱

$$
n=A_{\mathrm{CC}} / A
$$

により表示し, $n=3 / 5$ 供試体は砕・転圧土が 5 分割のうち 3 分割分を占めていることを示す。

供試体を分割した各部分の垂直応力 $\sigma_{\mathrm{Zi}}(\mathrm{i}=1 \sim 5)$ は 5 分 割された供試体の上端面にそれぞれ独立に加えた垂直荷 重の測定值 $\Delta P_{\mathrm{Zi}}(\mathrm{i}=1 \sim 5)$ から, 供試体全体のせん断応力 $\tau_{\mathrm{ZX}}$ はせん断中に測定されたせん断力 $S$ から

によりそれぞれ求めた。

$$
\sigma_{\mathrm{Zi}}=\sum \Delta P_{\mathrm{Zi}} / A \quad, \tau_{\mathrm{ZX}}=S / A
$$

\section{2 試料と供試体の作製}

1) 試料の物理的特性

合成土供試体のうち, 既設堤体, あるいは通常の築堤土 による堤体ゾーンを想定した供試体部分は広島県内の造 成工事で採取したまさ土を粒径 $19 \mathrm{~mm}$ 以上分のみカット して使用した。まさ土は, 図 5 に粒度曲線を示すように, 最大粒径 $D_{\max }=19 \mathrm{~mm}$, 細粒分含有率 $F_{\mathrm{C}} \doteqdot 0 \%$, 均等係数 $U_{\mathrm{C}} \doteqdot 16.0$ の粒度特性にある。まさ土の締固め特性は, 締固 め試験（JIS A1210の A 法）から得られた締固め曲線を図 6 に示寸ように, 最大乾燥密度が $\rho_{\mathrm{dmax}}=1.85 \mathrm{~g} / \mathrm{cm}^{3}$, 最適含 水比が $w_{\mathrm{opt}}=13.7 \%$ である。また, 砕·転圧土ゾーンを想定 


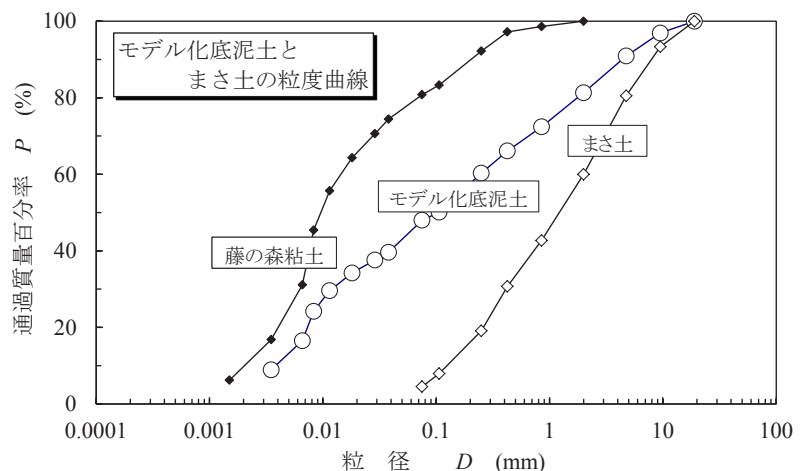

図5 藤の森粘土，まさ土，モデル化底泥土の粒度曲線

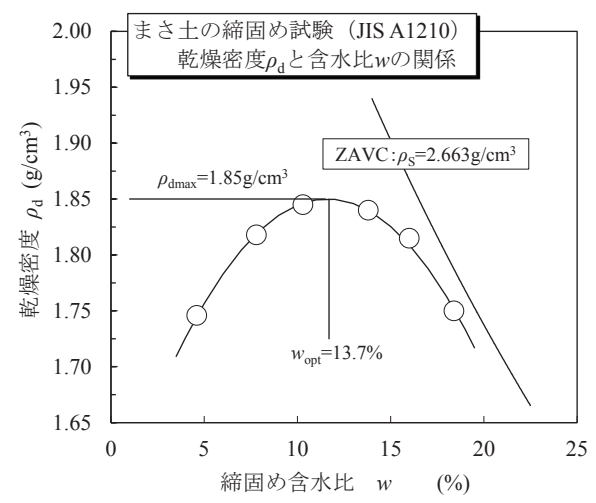

図 6 まさ土の締固め曲線

した供試体部分は乾燥状態で購入した藤の森粘土と上述 したまさ土を加えて粒度調整したモデル化底泥土を固化 改良して砕・転圧土を準備した。藤の森粘土は，図 5 に粒 度曲線を示すように, $D_{\max }=2.0 \mathrm{~mm}, F_{\mathrm{C}}=80.8 \%, U_{\mathrm{C}}=6.5$ の 粒度特性にあり, 塑性指数が $I_{\mathrm{P}}=19.2$ (液性限界 $w_{\mathrm{L}}=46.0 \%$, 塑性限界 $w_{\mathrm{P}}=26.8 \%$ ）である。

モデル化底泥土は含水比 $w=60 \%$ に水分調整した藤の森 粘土（体積 $V_{\mathrm{F}}$ ) に, $w=w_{\mathrm{opt}}$ になるように含水調整したまさ 土（体積 $V_{\mathrm{G}}$ ) を体積混合比で

$$
n_{\mathrm{V}}=V_{\mathrm{G}} / V_{\mathrm{F}}=0.5
$$

となるように加えて準備した（この状態における含水比は $w_{\mathrm{O}} \fallingdotseq 35 \%$ であった)。試料準備は質量比, すなわち藤の森 粘土の質量 $M_{\mathrm{F}}=\rho_{\mathrm{tF}} \cdot V_{\mathrm{F}}$ とまさ土の質量 $M_{\mathrm{G}}=\rho_{\mathrm{tG}} \cdot V_{\mathrm{G}}$ から

$$
n_{\mathrm{W}}=M_{\mathrm{G}} / M_{\mathrm{F}}=\left(\rho_{\mathrm{tG}} / \rho_{\mathrm{tF}}\right) \cdot\left(V_{\mathrm{G}} / V_{\mathrm{F}}\right)=\left(\rho_{\mathrm{tG}} / \rho_{\mathrm{tF}}\right) \cdot n_{\mathrm{V}}
$$

により行った。 $\rho_{\mathrm{tF}}$ と $\rho_{\mathrm{tG}}$ はそれぞれ藤の森粘土とまさ土の 湿潤密度で, 藤の森粘土では $w=60 \%$ 時の值 $\rho_{\mathrm{tF}}=1.60 \mathrm{~g} / \mathrm{cm}^{3}$ を,まさ土では締固め度 $D_{\mathrm{C}}=95 \%$ 相当の值

$$
\rho_{\mathrm{tG}}=D_{\mathrm{C}} \cdot \rho_{\mathrm{dmax}} \cdot\left(1+w_{\mathrm{opt}} / 100\right)=1.998 \mathrm{~g} / \mathrm{cm}^{3}
$$

を採用した。また，モデル化底泥土の湿潤密度 $\rho_{\mathrm{t}}$ は質量 $M=M_{\mathrm{F}}+M_{\mathrm{G}}$ と体積 $V=V_{\mathrm{F}}+V_{\mathrm{G}}$ から

$$
\rho_{\mathrm{t}}=M / V=\left(\rho_{\mathrm{tF}}+\rho_{\mathrm{tG}} \cdot n_{\mathrm{V}}\right) /\left(1+n_{\mathrm{V}}\right)
$$

により算定した。モデル化底泥土は, 図 5 に示した粒度曲 線のように， $D_{\max }=19.0 \mathrm{~mm}, F_{\mathrm{C}}=48.0 \%, U_{\mathrm{C}}=62.5$ にあり， また $\left.I_{\mathrm{P}}=14.3 （ w_{\mathrm{L}}=40.4 \%, \quad w_{\mathrm{P}}=26.1 \%\right)$ である。
表 1 藤の森粘土, まさ士，モデル化底泥土の物理特性

\begin{tabular}{c|c|c|c|c|c}
\hline 試 料 & $D_{\operatorname{macx}}(\mathrm{mm})$ & $U_{\mathrm{C}}$ & $F_{\mathrm{C}}(\%)$ & $I_{\mathrm{P}}$ & $w(\%)$ \\
\hline 藤の森粘土 & 2.0 & 6.5 & 80.8 & 19.2 & 60.0 \\
\hline まさ 土 & 19.0 & 16.0 & 0.0 & - & $13.7\left(=w_{\mathrm{opt}}\right)$ \\
\hline モデルル化底泥土 & 19.0 & 62.5 & 48.0 & 14.3 & 35.0 \\
\hline
\end{tabular}

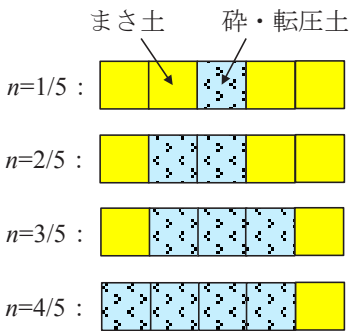

図 7 合成土供試体の砕・転圧土とまさ土の面積構成比

試験に用いたまさ土と藤の森粘土, モデル化底泥土の物 理特性は表 1 にそれぞれ示す。

モデル化底泥土に藤の森粘土を用いた理由は底泥土の ように時間経過による材料変質がなくいつでも同じ試料 を準備できること,まさ土を加えて粒度調整した理由は粗 粒分をある程度含む試料を再現するためである。

\section{2) まさ土部分の供試体の作製}

まさ土部分の供試体は, まさ土の含水比を $w_{\mathrm{opt}}=13.7 \%$ に 調整し, せん断箱内に 3 層に分けて質量 $1.525 \mathrm{~kg}$, 突固め 面が正方形 $100 \mathrm{~mm} \times 100 \mathrm{~mm}$ の突固めランマー（落下高さ $20 \mathrm{~cm}$ ）用いて締固め度 $D_{\mathrm{C}}=95 \%$ に相当する締固めエネル ギーで突き固めて作製した。

\section{3）砕・転圧土部分の供試体の作製}

砕·転圧土部分の供試体はモデル化底泥土をセメント系 固化材（一般軟弱土用）により固化改良して次に示すよう な方法で準備した。先ず，モデル化底泥土として，藤の森 粘土とまさ土を $n_{\mathrm{V}}=0.5$ で合わせて小型ミキサーで 2 分間 擋拌混合して準備した。これに水/セメント比 $\mathrm{w} / \mathrm{c}=1.0$ で所 定の固化材添加量 $\Delta M_{\mathrm{C}}$ になるようにスラリー化した固化 材を加えて 2 分間擋挥混合して, 直径 $D=100 \mathrm{~mm}$ と高さ $H=200 \mathrm{~mm}$ の円柱成型モールド内に詰め, $t_{\mathrm{S}}=3$ 日間養生さ せた初期固化土を準備した。そして, 砕・転圧土部の供試 体は, 初期固化土をモールドから取り出してストレートエ ッジにより辺長 10〜 $15 \mathrm{~mm}$ 程度のサイコロ状に解砕し, 試 験機のせん断箱内の所定の分割区分内に 3 層に分けて突 き固めて作製した。突固めは締固め試験（JGST711）の突 固め方法の $\mathrm{A}$ 法と同じ締固めエネルギー $E_{\mathrm{C}} \fallingdotseq 551 \mathrm{~kJ} / \mathrm{m}^{3}$ に なるように, 各層について上述した突固めランマーにより 行った。

図 7 には面積構成比を $n=1 / 5,2 / 5,3 / 5,4 / 5$ と変えた合 成土供試体の砕・転圧土部とまさ土部の配置を示す。砕・ 転圧土部はまさ土部に挟まれるように配置しているのは 図 3 に示したような堤体改修ゾーニングを想定したもの である。写真 3 には $n=3 / 5$ の合成土供試体の例を示す。 


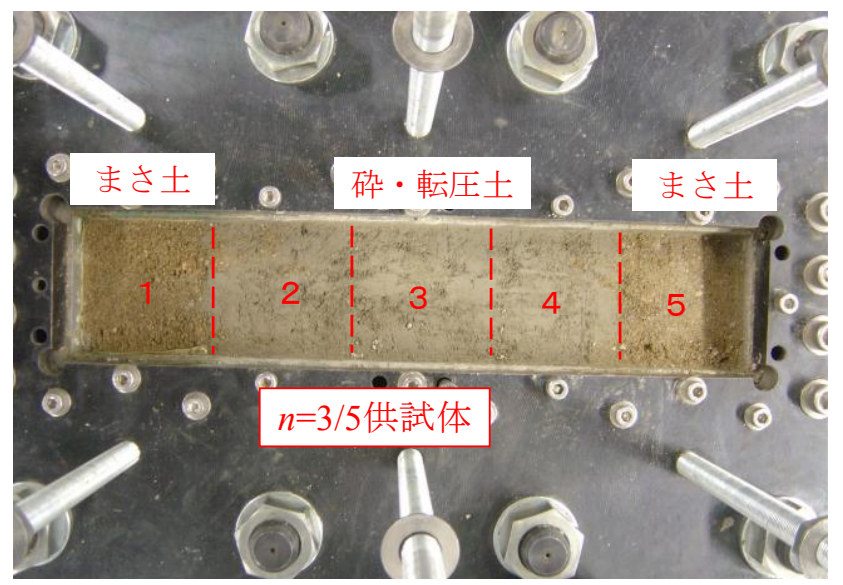

写真3 面積構成比 $n=3 / 5$ の合成土供試体の例

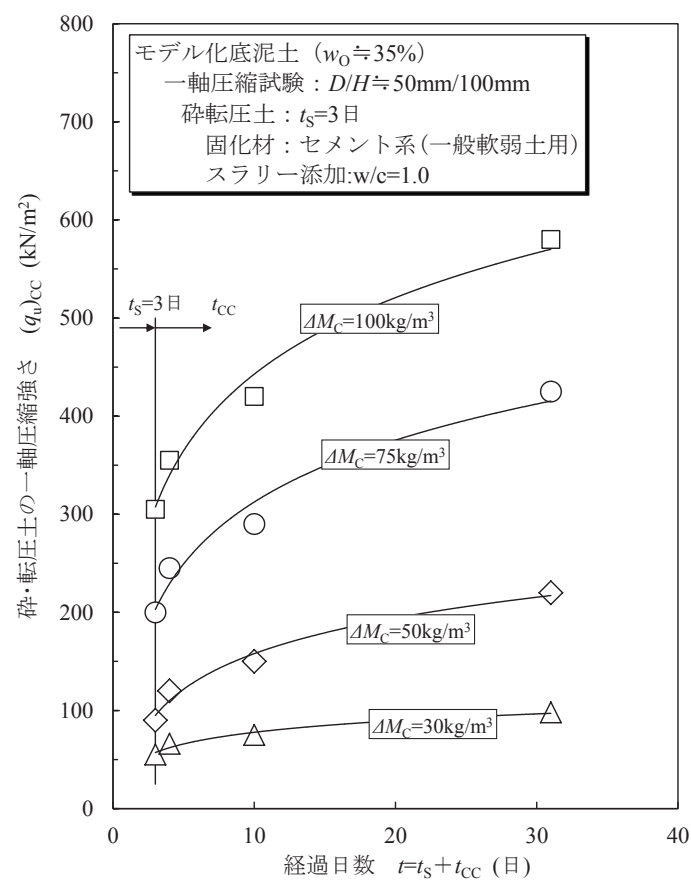

図 8 砕·転圧土の $\left(q_{\mathrm{u}}\right)_{\mathrm{CC}}$ の発現過程

強度が異なる砕・転圧土の準備は，事前に $\Delta M_{\mathrm{C}}$ を変えて 作製した砕・転圧土の一軸圧縮試験と一面せん断試験をそ れぞれ実施して強度と $\Delta M_{\mathrm{C}}$ の関係を求めておき，強度に 応じて $\Delta M_{\mathrm{C}}$ を変えることで行った。図 8 は試験から得ら れた砕・転圧土の一軸圧縮強さ $\left(q_{\mathrm{u}}\right)_{\mathrm{CC}}$ と経過期間 $t=t_{\mathrm{S}}+t_{\mathrm{CC}}$ に よる強度発現過程を示す。図 9 は図 8 から読み取った $t=t_{\mathrm{S}}+$ $t_{\mathrm{CC}}=3+7=10$ 日目の $\left(q_{\mathrm{u}}\right)_{\mathrm{CC}}$ と $\Delta M_{\mathrm{C}}$ の関係を示し, $\left(q_{\mathrm{u}}\right)_{\mathrm{CC}} \sim \Delta M_{\mathrm{C}}$ 関係は直線

$$
\Delta M_{\mathrm{C}}=16+0.201 \cdot\left(q_{\mathrm{u}}\right)_{\mathrm{CC}}
$$

により近似した。所要の $\left(q_{\mathrm{u}}\right)_{\mathrm{CC}}$ の砕・転圧土の供試体を準備 するのに必要な $\Delta M_{\mathrm{C}}$ は式(2)から算定した。

なお, 粘着力 $c_{\mathrm{CC}}$ と $\left(q_{\mathrm{u}}\right)_{\mathrm{CC}}$ の関係は, $\Delta M_{\mathrm{C}}$ を変えて準備 した砕・転圧土単体の供試体の一面せん断試験から求めた $c_{\mathrm{CC}}$ (最大せん断応力 $\tau_{\mathrm{f}}$ と $\sigma_{\mathrm{Z}}$ の関係を直線近似したときの 切片から求めた）を $\left(q_{\mathrm{u}}\right)_{\mathrm{CC}}$ に対してプロットした図 10 の $c_{\mathrm{CC}} \sim\left(q_{\mathrm{u}}\right)_{\mathrm{CC}}$ 関係

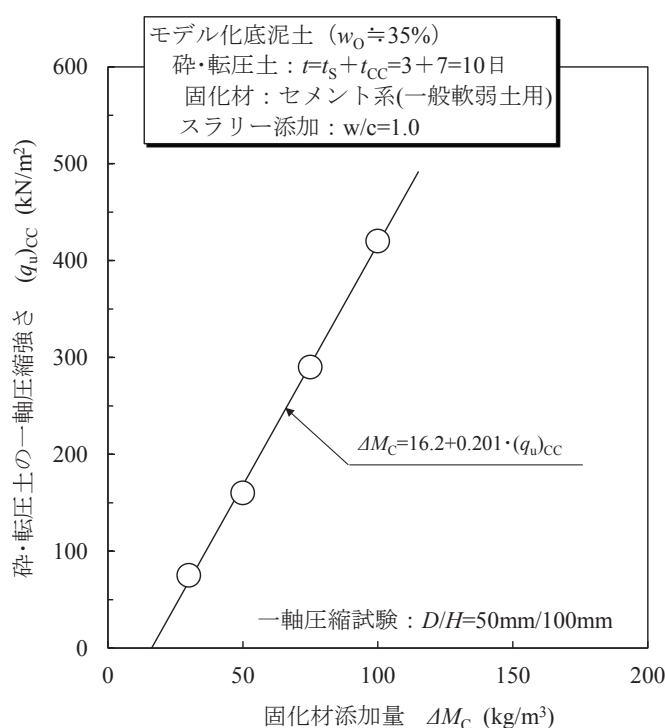

図 9 砕·転圧土の $\left(q_{\mathrm{u}}\right)_{\mathrm{CC} 7} \sim \Delta M_{\mathrm{C}}$ 関係

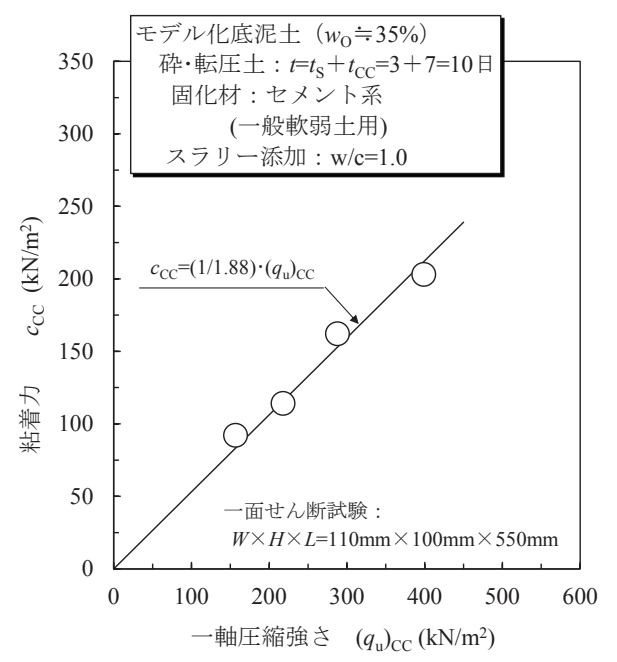

図 10 砕·転圧土の $c_{\mathrm{CC}} \sim\left(q_{\mathrm{u}}\right)_{\mathrm{CC}}$ 関係

$$
c_{\mathrm{CC}}=(1 / 1.88) \cdot\left(q_{\mathrm{u}}\right)_{\mathrm{CC}}
$$

を使用した。

\section{3 合成土の一面せん断強度特性}

合成土供試体の分割載荷型一面せん断試験は初期固化 期間 $t_{\mathrm{S}}=3$ 日の初期固化土を解砕 - 突固めて砕 - 転圧土を 準備してから $t_{\mathrm{CC}}=7$ 日が経過した $t=t_{\mathrm{S}}+t_{\mathrm{CC}}=3+7=10$ 日目に実 施した。試験はすべて砕・転圧土部分とまさ土部分の $\sigma_{\mathrm{Z}}$ をそれぞれ一定にして，下部せん断箱を毎分 $\delta X=0.25 \mathrm{~mm}$ で強制変位させて実施した。砕・転圧土部分の目標強度は $c_{\mathrm{CC}}=100,150,200 \mathrm{kN} / \mathrm{m}^{2}$ の 3 種類に設定し, これらを準備 できる $\Delta M_{\mathrm{C}}$ は $c_{\mathrm{CC}}$ を式(3)により $\left(q_{\mathrm{u}}\right)_{\mathrm{CC}}$ に変換した $\left(q_{\mathrm{u}}\right)_{\mathrm{CC}} \fallingdotseq$ 190，290，380kN/m² を式(2)に代入して求めた。

図 11 はまさ土単体の供試体 $(n=0 / 5)$ について $\sigma_{\mathrm{Z}}$ を $\sigma_{\mathrm{Z}}=35$, $70,140 \mathrm{kN} / \mathrm{m}^{2}$ と変えた試験から得られたせん断応力 $\tau_{\mathrm{Zx}}$ と せん断変位 $\delta X$ の関係を示す。図 12 は一軸圧縮強さによる 強度レベルを $\left(q_{\mathrm{u}}\right)_{\mathrm{CC}} \fallingdotseq 190 \mathrm{kN} / \mathrm{m}^{2}$ として準備した砕・転圧土 


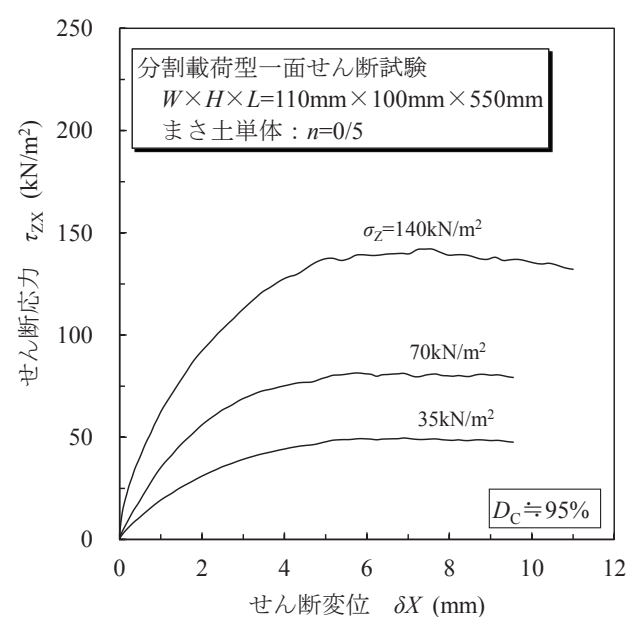

図11 まさ土単体 $(n=0 / 5)$ の $\tau_{\mathrm{ZX}} \sim \delta X$ 関係

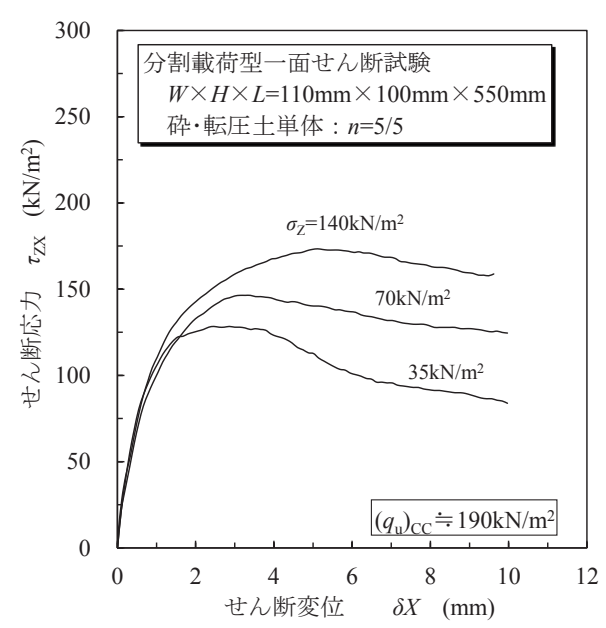

図12 砕·転圧土 $(n=5 / 5)$ の $\tau_{\mathrm{ZX}} \sim \delta X$ 関係

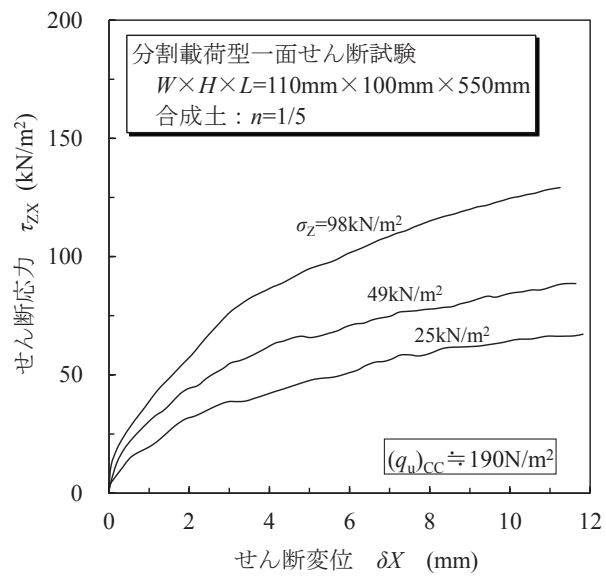

図 13 合成土 $(n=1 / 5)$ の $\tau_{\mathrm{ZX}} \sim \delta X$ 関係

だけからなる供試体 $(n=5 / 5)$ の $\tau_{\mathrm{ZX}} \sim \delta X$ 関係を示す。図 11 から，まさ土単体の供試体 $(n=0 / 5)$ の $\tau_{\mathrm{ZX}} \sim \delta X$ 関係は せん断初期から発揮される $\tau_{\mathrm{ZX}}$ が $\sigma_{\mathrm{Z}}$ により異なり摩擦性材 料の特徴を示していることがわかる。一方, 図 12 から, 砕·転圧土単体 $(n=5 / 5)$ の $\tau_{\mathrm{ZX}} \sim \delta X$ 関係ではせん断初期に

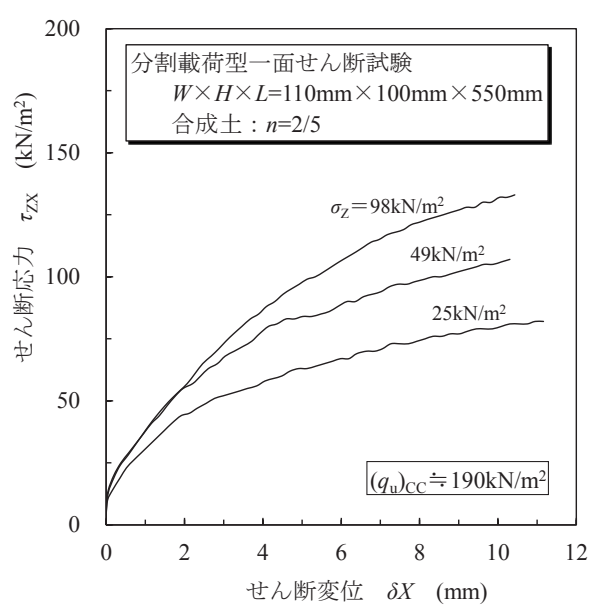

図 14 合成土 $(n=2 / 5)$ の $\tau_{\mathrm{ZX}} \sim \delta X$ 関係

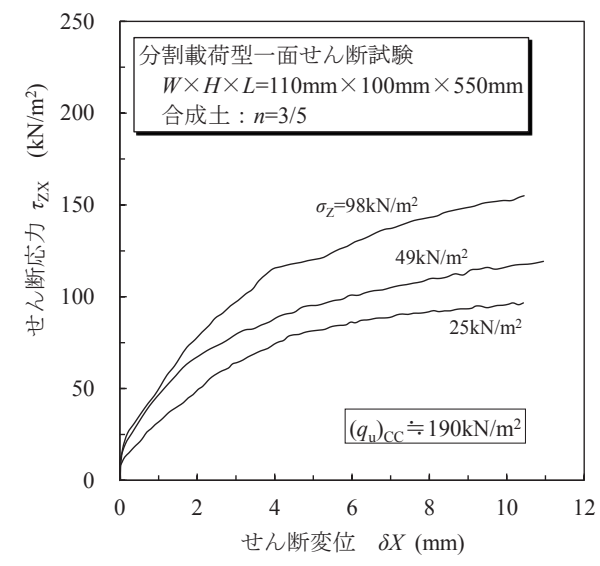

図15 合成土 $(n=3 / 5)$ の $\tau_{Z X} \sim \delta X$ 関係

おいて発揮される $\tau_{\mathrm{ZX}}$ は $\sigma_{\mathrm{Z}}$ による差がほとんどないものの, せん断変形が $\delta X=3 \sim 4 \mathrm{~mm}$ まで進行すると $\sigma_{\mathrm{Z}}$ による相違が 現れることがわかる。このことは, 粘着力に卓越した砕・ 転圧土であっても $\delta X$ の増加によりすべり面が形成される ような段階になると，土のような摩擦性材料と似た挙動を 示すためと考えられる。

図 13, 図 14, そして図 15 は $\left(q_{\mathrm{u}}\right)_{\mathrm{CC}} \doteqdot 190 \mathrm{kN} / \mathrm{m}^{2}$ の砕·転圧 土を $n=1 / 5,2 / 5,3 / 5$ の割合で作製した合成土供試体の $\sigma_{\mathrm{Z}}=25,49,98 \mathrm{kN} / \mathrm{m}^{2}$ と変えた試験から得られた $\tau_{\mathrm{ZX}} \sim \delta X$ 関 係をそれぞれ示寸。これらの図から，合成土の $\tau_{Z X} \sim \delta X$ 関 係はせん断初期から発揮される $\tau_{\mathrm{ZX}}$ に $\sigma_{\mathrm{Z}}$ による相違が現れ ているものの, その相違がまさ土単体よりも少なく, 砕. 転圧土単体より大きく, 両者の中間的な挙動を示している ことがわかる。

図 16 は合成土供試体の試験から得られたせん断強度 $\tau_{\mathrm{f}}$ と $\sigma_{\mathrm{Z}}$ の関係を示す。 $\tau_{\mathrm{f}}$ は $\tau_{\mathrm{ZX}}$ のピーク值とし， $\tau_{\mathrm{ZX}}$ にピーク 值が現れない場合には $\delta X=10 \mathrm{~mm}$ における值とした。図 17 と図 18 は, 砕・転圧土の強度レベルを $\left(q_{\mathrm{u}}\right)_{\mathrm{CC}} \fallingdotseq 290$, $380 \mathrm{kN} / \mathrm{m}^{2}$ とした合成土に関する同様の試験から得られた $\tau_{\mathrm{f}} \sim \sigma_{\mathrm{Z}}$ 関係をそれぞれ示す。

合成土供試体の $\tau_{\mathrm{f}}$ は, 茨木の研究 $(1965)^{4)}$ と同様に, 砕. 転圧土とまさ土の各構成土が一体として抵抗し, 砕·転圧 


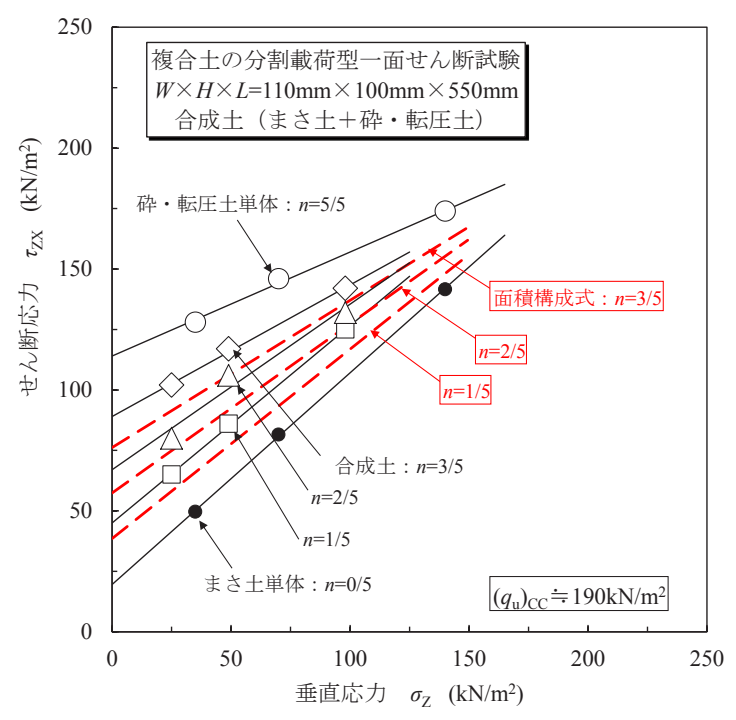

図16 せん断強度 $\tau$ と垂直応力 $\sigma_{\mathrm{Z}}$ の関係 $\left(\left(q_{\mathrm{u}}\right)_{\mathrm{CC}} \fallingdotseq 190 \mathrm{kN} / \mathrm{m}^{2}\right)$

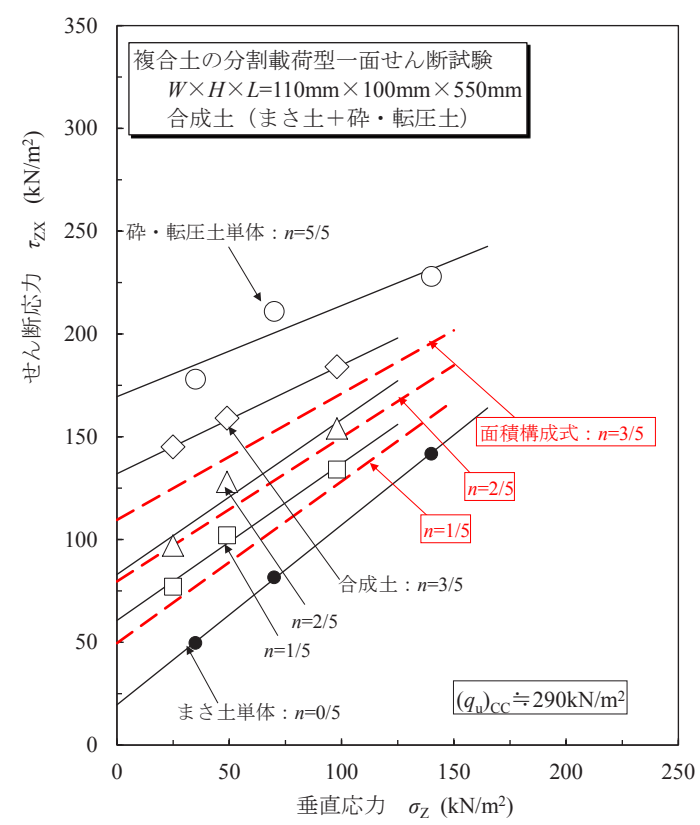

図 17 せん断強度 $\tau$ と垂直応力 $\sigma_{\mathrm{Z}}$ の関係 $\left(\left(q_{\mathrm{u}}\right)_{\mathrm{CC}} \fallingdotseq 290 \mathrm{kN} / \mathrm{m}^{2}\right)$

土単体の $\tau_{\mathrm{CC}}$ と突固めたまさ土単体の $\tau_{\mathrm{S}}$ が同一の変位で発 揮されるとして, 各部分で発揮される強度の合計值である $\tau \cdot A=\tau_{\mathrm{CC}} \cdot A_{\mathrm{CC}}+\tau_{\mathrm{S}} \cdot A_{\mathrm{S}}$ から

$$
\tau_{\mathrm{f}}=(1-n) \cdot \tau_{\mathrm{S}}+n \cdot \tau_{\mathrm{CC}}
$$

により表示できるものとする。砕・転圧土の $\tau_{\mathrm{CC}}$, あるいは まさ土の $\tau_{\mathrm{S}}$ はそれぞれの $\tau_{\mathrm{f}} \sim \sigma_{\mathrm{Z}}$ 関係を直線近似すると

$$
\begin{aligned}
& \tau_{\mathrm{S}}=c_{\mathrm{S}}+\sigma \cdot \tan \phi \mathrm{S} \\
& \tau_{\mathrm{CC}}=c_{\mathrm{CC}}+\sigma \cdot \tan \phi \mathrm{CC}
\end{aligned}
$$

として表示できる。 $c_{\mathrm{S}}$ と $\phi_{\mathrm{S}}$ はまさ土単体 $(n=0 / 5)$ の粘着 力と内部摩擦角であり, 図 16 におけるまさ土の $\tau_{\mathrm{f}} \sim \sigma_{\mathrm{Z}}$ 関係

（の印）を近似した直線の切片と傾きから求めると

$$
c_{\mathrm{S}}=19.6 \mathrm{kN} / \mathrm{m}^{2}, \quad \phi_{\mathrm{S}}=41.1^{\circ}
$$

であった。また， $c_{\mathrm{CC}}$ と $\phi_{\mathrm{CC}}$ は砕・転圧土単体 $(n=5 / 5)$ の粘 着力と内部摩擦角であり, $\left(q_{\mathrm{u}}\right)_{\mathrm{CC}} \fallingdotseq 190 \mathrm{kN} / \mathrm{m}^{2}$ の砕・転圧土で

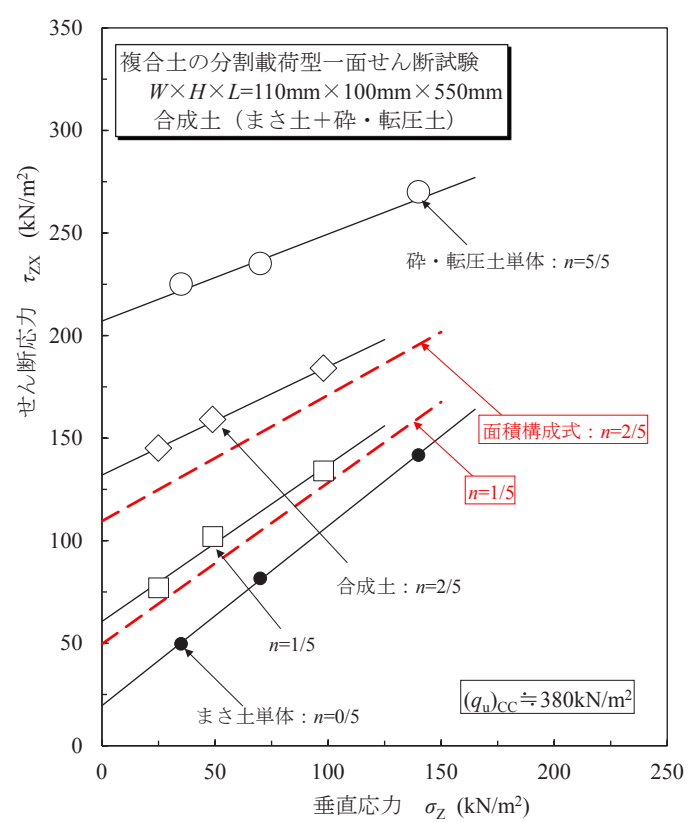

図 18 せん断強度 $\tau$ と垂直応力 $\sigma_{\mathrm{Z}}$ の関係 $\left(\left(q_{\mathrm{u}}\right)_{\mathrm{CC}} \fallingdotseq 380 \mathrm{kN} / \mathrm{m}^{2}\right)$

\begin{tabular}{c|c|c|c} 
表2 & 砕·転圧土の目標強度レベルと $\left(c_{\mathrm{CC}}, \phi_{\mathrm{CC}}\right)$ \\
\hline \multicolumn{2}{c|}{ 目標強度レベル } & \multicolumn{2}{|c}{ 強度パラメータ } \\
\hline$c_{\mathrm{CC}}\left(\mathrm{kN} / \mathrm{m}^{2}\right)$ & $\left(q_{\mathrm{u}}\right)_{\mathrm{CC}}\left(\mathrm{kN} / \mathrm{m}^{2}\right)$ & $c_{\mathrm{CC}}\left(\mathrm{kN} / \mathrm{m}^{2}\right)$ & $\left.\phi_{\mathrm{CC}}{ }^{\circ}\right)$ \\
\hline 100 & 190 & 114 & 23.1 \\
\hline 150 & 290 & 170 & 23.0 \\
\hline 200 & 380 & 207 & 25.5 \\
\hline
\end{tabular}

は図16に示した $\tau_{\mathrm{f}} \sim \sigma_{\mathrm{Z}}$ 関係（○印）を近似した直線の切片 と傾きから求めると

$$
c_{\mathrm{CC}}=114 \mathrm{kN} / \mathrm{m}^{2}, \quad \phi_{\mathrm{CC}}=23.1^{\circ}
$$

であった。目標強度レベルを $\left(q_{\mathrm{u}}\right)_{\mathrm{CC}} \fallingdotseq 290 \mathrm{kN} / \mathrm{m}^{2}$ と $\left(q_{\mathrm{u}}\right)_{\mathrm{CC}} \fallingdotseq$ $380 \mathrm{kN} / \mathrm{m}^{2}$ として準備した砕·転圧土の $\left(c_{\mathrm{CC}}, \phi_{\mathrm{CC}}\right)$ も同様 に図17と図18にそれぞれ示してある。表2は以上のように 得られた強度レベルを変えた砕・転圧土単体の強度パラメ 一タを示す。

合成土の $\tau_{\mathrm{f}} \sim \sigma_{\mathrm{Z}}$ 関係は式(4)に式(5)と式(6)を代入して整 理した強度パラメータ, 寸なわち合成粘着力成分 $c_{\mathrm{T}}$ と合成 内部摩擦角 $\phi_{\mathrm{T}}$ により

$$
\tau_{\mathrm{f}}=c_{\mathrm{T}}+\sigma \cdot \tan \phi \mathrm{T}
$$

に表示でき，それぞれの合成成分は

$$
\begin{aligned}
& c_{\mathrm{T}}=(1-n) \cdot c_{\mathrm{S}}+n \cdot c_{\mathrm{CC}} \\
& \tan \phi_{\mathrm{T}}=(1-n) \cdot \tan \phi_{\mathrm{S}}+n \cdot \tan \phi_{\mathrm{CC}}
\end{aligned}
$$

となる。図16, 図17, 図18に示した太い直線は, $n=1 / 5$, 2/5，3/5の合成土について $n$ に関する式(8)と式(9)を用いた 式(7)により推定した $\tau_{\mathrm{f}} \sim \sigma_{\mathrm{Z}}$ 関係をそれぞれ示している。図 から，合成土の $\tau_{\mathrm{f}}$ は式(7)により推定される值に近いもの の，やや大きい值となっていることがわかる。また，強度 レベル $\left(q_{\mathrm{u}}\right)_{\mathrm{CC}}$ が高いほど, この傾向の顕著なこともわかる。 この原因については，砕・転圧土部とまさ土部における強 度が同一の変位において発揮されるわけではないことや, 


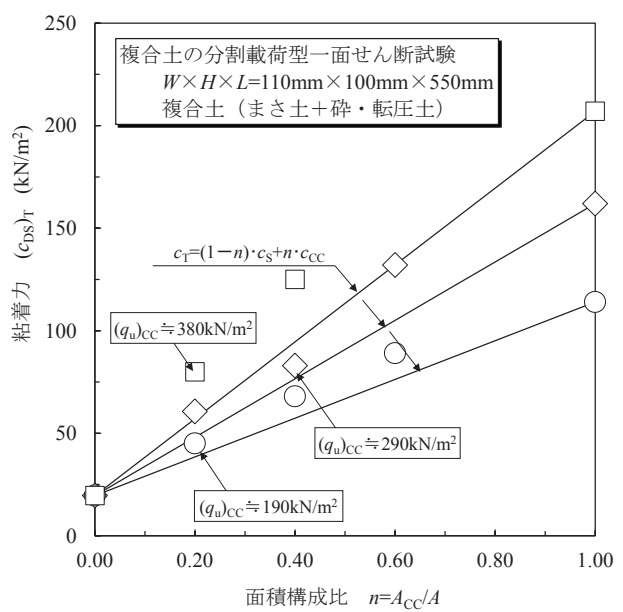

図19 合成土の粘着力 $c_{\mathrm{T}}$ と面積構成比 $n$ の関係

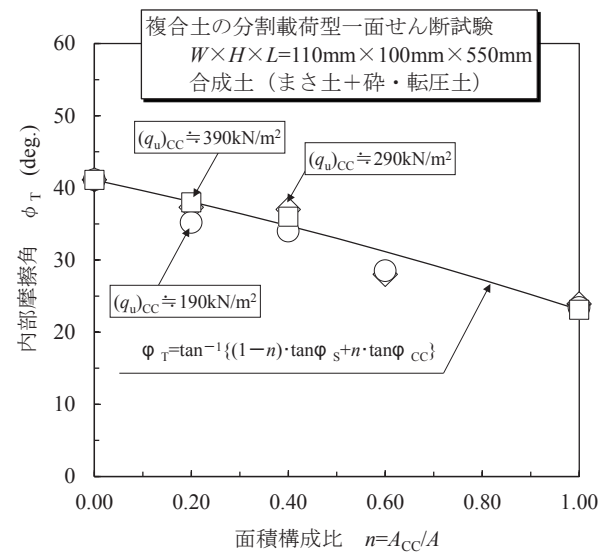

図20 合成土の内部摩擦角 $\phi_{\mathrm{T}}$ と面積構成比 $n$ の関係

砕・転圧土の強度レベルが高いほどまさ土との変位特性の 相違の影響が大きく現われてくるものと考えられるが，ゾ ーン型構造堤体の安定性評価するには $n$ の值を用いて近似 的に推定できるものと考えてよいだろう。

図19は以上の合成土の試験から得られた $c_{\mathrm{T}}$ と $n$ の関係を 強度レベル毎にそれぞれ示す。図中の直線は式(8)の関係で ある。図から，試験による $c_{\mathrm{T}} \sim n$ 関係は式(8)により表示さ れる直線関係より大きい值になっているものの, $c_{\mathrm{T}}$ が $n$ と ともに増加する傾向をある程度近似できることがわかる。 また，図20は同様に得られた合成土の $\phi_{\mathrm{T}}$ と $n$ の関係を $\left(q_{\mathrm{u}}\right)_{\mathrm{CC}}$ 毎にそれぞれ示す。図中の曲線は式(9)の関係である。 図から， $\phi_{\mathrm{T}} \sim n$ 関係は砕・転圧土の強度レベルによらず式 (9)によりうまく近似できることがわかる。

図21は，まさ土単体 $(n=0 / 5)$ の $\tau_{\mathrm{f}} \sim \sigma_{\mathrm{Z}}$ 関係と，強度レべ ル $\left(q_{\mathrm{u}}\right)_{\mathrm{CC}}$ が異なる3 種類の砕・転圧土単体 $(n=5 / 5)$ の $\tau_{\mathrm{f}} \sim \sigma_{\mathrm{Z}}$ 関係の比較を示したもので， $\sigma_{\mathrm{Z}} \leqq 150 \mathrm{kN} / \mathrm{m}^{2}$ においては砕・ 転圧土とまさ土の間の強度差が2〜4倍程度あったことに なる。したがって, 合成土の強度は, 砕・転圧土とまさ土 の間の強度差が2〜4倍程度内であれば, すべり面上に沿っ た各部分で発揮される強度の割合であるnの值による成分 合計により表せる, すなわち安定計算上の複合土地盤とし て考えることができよう。

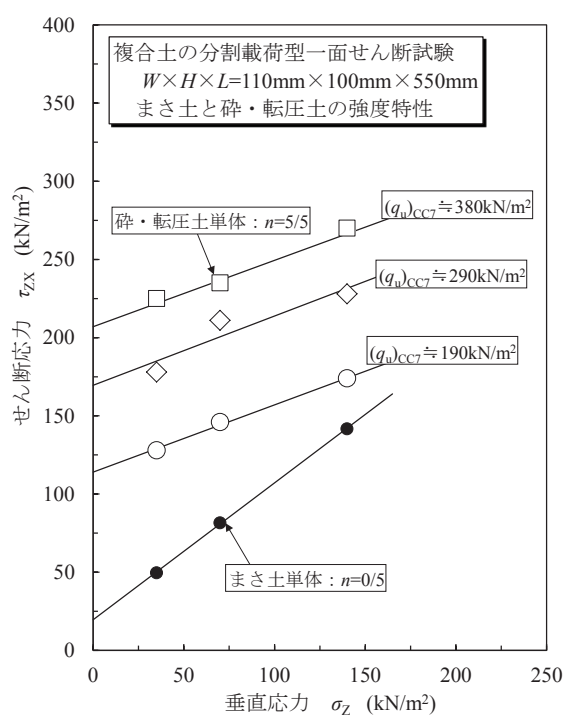

図21 まさ土と砕·転圧土の $\tau_{\mathrm{f}} \sim \sigma_{\mathrm{Z}}$ 関係

\section{4. 砕・転圧土ゾーンの強度許容值の提案}

上述した試験結果から，砕・転圧土ゾーンで発揮される $\tau_{\mathrm{CC}}$ と既設堤体で発揮される $\tau_{\mathrm{S}}$ の差がおおよそ

$$
\tau_{\mathrm{CC}} / \tau_{\mathrm{S}} \leqq 4.0
$$

であっても，堤体全体を複合土として扱えることが示され た。したがって，砕・転圧盛土工法により改修した堤体全 体の安定計算は，砕・転圧土ゾーンと既設堤体の間に強度 差が上記範囲にあれば，ロックフィルダムの場合と同様に 円弧すべり面を仮定して行うことができよう。

堤体改修を砕・転圧盛土工法により図2の下図に示した ようなゾーニングパターンで行った場合を想定すると， 砕・転圧土ゾーンが堤体全体内のすべり面上で占める割合 は堤高 $H=20 \sim 30 \mathrm{~m}$ においてはおおよそ2～3割と考えられ る。図19に示した $c_{\mathrm{T}} \sim n$ 関係において, $n=0.2 \sim 0.3$ に対応寸 る $c_{\mathrm{T}}$ は式(8)による面積構成合成值よりも高い傾向を示す ものの，目標強度レベルが低いほど近似程度がよい。すな わち, 砕・転圧土ゾーンの強度レベルは隣接ゾーンに対し て差が少ない方が複合土地盤としての取扱い上有利であ ることを意味している。

砕・転圧土ゾーンと既設堤体との間の強度差は, 中央コ ア型ロックフィルダムにおいて, 堤体安定機能を受け持つ ロックゾーンと貯水機能を受け持つコアゾーンとの間の 強度差に近いものと考えられる。ロックゾーンは堤体内の 強度の高い部分であり, 粘着力を期待できないものの内部 摩擦角が大きい強度特性にある。コアゾーンは堤体内の強 度の低い部分であり, 粘着力を期待できるものの内部摩擦 角が小さい強度特性にある。これらのロックゾーンとコア ゾーンの間の強度差は 2 倍程度の相違があることが認め られている ${ }^{5)}$

本稿で対象としているような築造年代の古い老朽化し た堤体は堤高がせいぜい $30 \mathrm{~m}$ 程度までである ${ }^{6}$ 。したがっ て, 既設堤体の外側に砕・転圧土ゾーンを腹付けした堤体 


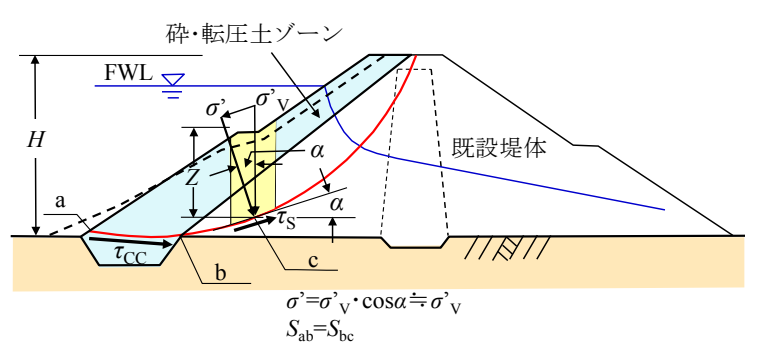

図 22 砕·転圧土ゾーンの目標強度の設定法

は, 本格的なロックフィルダムに比較して, 堤高が低いこ とや砕・転圧土ゾーン・既設堤体間の境界面勾配がロック フィルダムにおけるロック・コアゾーン間の境界面勾配に 比較してかなり緩く, 地震時応答の影響が相対的に小さい など, 許容できる強度差に余裕があると考えられる。そこ で，ここでは砕・転圧土ゾーンと既設堤体との間の強度差 の許容值として, 以上の試験で確認された範囲の上限值に 近い

$$
\tau_{\mathrm{CC}} / \tau_{\mathrm{S}} \leqq 3.0
$$

とすることを提案する。

なお，砕・転圧土ゾーンの $\tau_{\mathrm{CC}}$ は既設堤体に期待できる $\tau_{\mathrm{S}}$ に対応させて決定する必要があり, $\tau_{\mathrm{CC}}$ と $\tau_{\mathrm{S}}$ の関係とし て図 22 に示すように考えることを提案したい。この図は 堤体の補強や漏水防止のための腹付けの場合における砕. 転圧土ゾーンを含む堤体全体に発生するすべり面を概念 的に示している。砕・転圧土ゾーン内のすべり面に発揮さ れる $\tau_{\mathrm{CC}}$ は砕・転圧土が粘着力成分である $\left(c^{\prime}\right)_{\mathrm{CC}}$ の卓越した 特性にあるため，すべり面上でほぼ一定として

$$
\tau_{\mathrm{CC}} \fallingdotseq\left(c^{\prime}\right)_{\mathrm{CC}}
$$

により表される。一方, 既設堤体内のすべり面に発揮され る $\tau_{\mathrm{S}}$ はすべり面上の有効垂直応力 $\sigma$ により変化し

$$
\tau_{\mathrm{S}}=c^{\prime}+\sigma^{\prime} \cdot \tan \phi,
$$

により表される。砕・転圧土ゾーンに隣接してこれと一体 として抵抗する既設堤体の代表的な $\tau_{\mathrm{S}}$ として, 砕·転圧土 ゾーンのすべり面上の幅 $S_{\mathrm{ab}}$ と同じすべり面幅 $S_{\mathrm{bc}}\left(=S_{\mathrm{ab}}\right)$ だけ既設堤体内部に入ったすべり面上において発揮され る值とする。この時の $\sigma^{\prime}$ はすべり面の角度 $\alpha$ がそう大きく ない範囲にあることから $\left(\alpha<20^{\circ} ， \cos \alpha \fallingdotseq 1.0\right)$

$$
\sigma^{\prime}=\sigma^{\prime}{ }_{\mathrm{V}} \cdot \cos \alpha \fallingdotseq \sigma_{\mathrm{V}}
$$

とおける。 $\sigma^{\prime}{ }_{\mathrm{V}}$ は既設堤体の水中単体重量 $\gamma^{\prime}\left(\fallingdotseq 8 \mathrm{kN} / \mathrm{m}^{3}\right)$, すべり面上の分割片土柱の高さを $Z$ とおくと

$$
\sigma^{\prime}{ }_{\mathrm{V}}=\gamma^{\prime} \cdot Z
$$

となる。既設堤体に発揮される強度の代表值 $\tau_{\mathrm{S}}$ は, 堤高を $H$ とするとおおよそ $Z \fallingdotseq H / 2$ とおけるから,$H=20$ 〜 $30 \mathrm{~m}$ で あることと $c^{\prime} \fallingdotseq 0 \mathrm{kN} / \mathrm{m}^{2}, \quad \phi ’ \fallingdotseq 30^{\circ}$ を想定すると

$$
\tau_{\mathrm{S}} \fallingdotseq \sigma^{\prime} \cdot \tan \phi^{\prime}=8 \times(10 \sim 15) \times \tan 30=46 \sim 70 \mathrm{kN} / \mathrm{m}^{2}
$$

程度となろう。したがって, 砕・転圧土ゾーンにおいて許 容できる最大の強度レベル $\tau_{\mathrm{CC}}$ は既設堤体で発揮される $\tau_{\mathrm{S}}$ に応じて

$$
\tau_{\mathrm{CC}} \leqq 3.0 \cdot \tau_{\mathrm{S}}=3 \times(46 \sim 70)=140 \sim 210 \mathrm{kN} / \mathrm{m}^{2}
$$

が許容值の目安となろう。

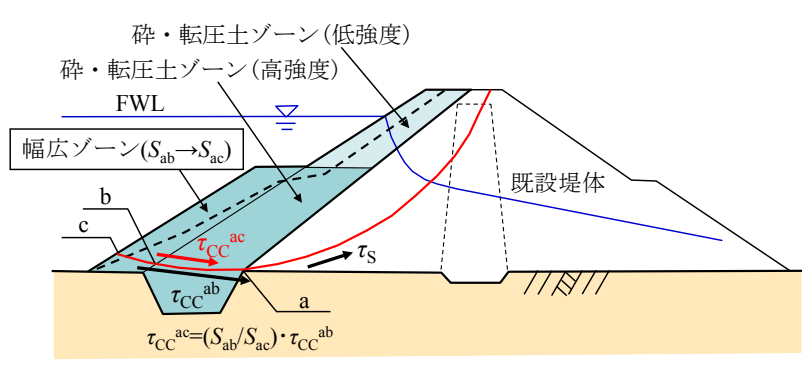

図23幅広の砕·転圧土ゾーンの採用

計画した堤体改修ゾーニングおける砕・転圧土ゾーンの 強度が許容值を超える場合にはゾーニングパターンを変 更することを検討する。例えば，砕・転圧土ゾーン内を図 22 に示すように地震時の変形が大きく強度差の影響が大 きいゾーン上層部を低強度レベルに, 地震時の変形が小さ く強度差による影響が相対的に少ないゾーン下層部を堤 体安定に効果的に機能するように高強度レベルとするよ うな強度ゾーニングを考える。このようにしても，依然と して両者の強度差が大き過ぎる場合には，砕・転圧土ゾー ンを図 23 に示すように幅広にしてすべり面長を $S_{\mathrm{ab}}$ から $S_{\mathrm{ac}}$ に拡大させることで強度レベルを

$$
\tau_{\mathrm{CC}}^{\mathrm{ac}}=\left(S_{\mathrm{ab}} / S_{\mathrm{ac}}\right) \cdot \tau_{\mathrm{CC}}^{\mathrm{ab}}
$$

のように低下させるようなゾーニングで対応する。

\section{5. おわりに}

砕・転圧盛土工法によるフィルダム堤体改修でのゾーニ ングの決定は, 砕・転圧土ゾーンとこれに隣接する既設堤 体等が一体として外力に抵抗できるように両者間に極端 な強度差のないようにする必要がある。

本稿は砕・転圧土ゾーンと既設堤体との間に極端な強度 差が生じないようにできる砕・転圧土ゾーンの強度におけ る許容值について, 砕・転圧土により改修した堤体全体の 破壊モードを再現した分割載荷型一面せん断試験により 検討し，以下のことを提案した。砕・転圧土ゾーンの強度 $\tau_{\mathrm{CC}}$ と隣接する既設堤体の強度 $\tau_{\mathrm{S}}$ の間の差がおおよそ

$$
\tau_{\mathrm{CC}} / \tau_{\mathrm{S}} \leqq 3.0
$$

であれば砕・転圧土ゾーンを含む堤体全体の安定計算では 砕・転圧土ゾーンを含む堤体全体を複合土として扱うこと ができる。砕・転圧土ゾーンの強度 $\tau_{\mathrm{CC}}$ 設定するために は既設堤体に期待できる強度 $\tau_{\mathrm{S}}$ が必要であり，これは砕・ 転圧土ゾーン内の寸べり面上の幅 $S_{\mathrm{ab}}$ と同じすべり面幅 $S_{\mathrm{bc}}$ $\left(=S_{\mathrm{ab}}\right)$ だけ既設堤体内部に入ったすべり面において発揮 される值とする。

\section{参 考 文 献}

1) (社)農業農村整備情報総合センター編 : ため池改修工事の効率 化，一砕·転圧盛土工法によるため池堤体改修一, 設計·施工・ 積算指針(案), (社)農業農村整備情報総合センター, 2006.

2) (社)農業農村整備情報総合センター編 : 砕・転圧盛土工法によ るフィルダム堤体改修, 一堆積土・発生土を有効活用したフィ 
ルダムのリニューアル技術一, 設計・施工・積算指針(案), (社) 農業農村整備情報総合センター，2009.

3) 福島伸二, 谷 茂: フィルダムにおける貯水池内底泥土の固化 改良土を用いた堤体耐震補強技術, 地盤工学会誌, Vol.61, No.1, pp.18-21, 2013.

4) 茨木龍雄: 複合土の直接セン断試験による実験的研究(第 1 報), 土と基礎, Vol.13, No.3, pp.19-24, 1965 .
5) Naylor, D.J., Maranha Das Nebes, E., Mattar Jr. D. and Veiga Pinto, A.A. : Prediction of Construction Performance of Beliche Dam, Geotechnique, Vol.36, No.3, pp.359-376, 1986.

6) (財)日本ダム協会ホームページ: ダム便覧 2013,

http://damnet.or.jp/Dambinran/binran/TopIndex.html

(2014.6.18 受付) 


\title{
STRENGTH CHARACTERISTICS ON COMPOSITE SOIL CONSISTED OF CEMENT-
} MIXED AND COMPACTED SOILS IN SEPARATE LOADING TYPE DIRECT SHEAR TEST

\author{
Shinji FUKUSHIMA ${ }^{1}$ and Akira KITAJIMA ${ }^{2}$ \\ 1 Civil Engineering Division, Fujita Corporation \\ 2 Technical and Research Center, Fujita Corporation
}

\begin{abstract}
In the reinforcement method by using the cement-mixed muddy soil for the fill type dam embankment, it is necessary to determine the zoning pattern to produce no an extremely large difference in strength between the reinforced zone by cement-mixed muddy soil and the existing embankment.

In this paper, the direct shear tests duplicated the failure mode of the embankment reinforced with the cement-mixed muddy soil was performed to investigate the allowable strength difference between the reinforced zone and the existing embankment. From the experimental results, we suggested that the embankment reinforcing with the cement-mixed muddy soil is regarded as a composite soil if the reinforced zone strength $\tau_{\mathrm{CC}}$ is approximately 3.0 times lower than or equal to the existing embankment strength $\tau_{\mathrm{s}}$.
\end{abstract}

Key words: fill type dam, embankment reinforcement, muddy soil, cement-mixed soil, composite soil 